\title{
GEOLOGY, GEOCHEMISTRY AND RADIOACTIVITY OF GRANITIC AND VOLCANIC ROCKS ATHADARBA AREA, SOUTH EASTERN DESERT, EGYPT
}

\section{HASSAN A. A. SHAHIN, MASOUD S. MASOUD AND MOUSTAFA M. BAYOUMI}

\author{
Nuclear Materials Authority, P. O. Box 530, El-Maadi, Cairo, Egypt
}

\begin{abstract}
The present work deals with geology, geochemistry, radioactivity and tectonic environment of the granitic and volcanic rocks at Hadarba area, South Eastern Desert of Egypt. The granitic rocks comprise tonalite-granodiorite and monzogranite, while the volcanic rocks include rhyolite, rhyodacite and dacite. These rocks are characterized by high concentrations of $\mathrm{SiO}_{2}$, $\mathrm{Na}_{2} \mathrm{O}, \mathrm{Fe}_{2} \mathrm{O}_{3}, \mathrm{~K} 2 \mathrm{O}, \mathrm{Zr}, \mathrm{Nb}$ and $\mathrm{Y}$ but low in $\mathrm{MgO}, \mathrm{CaO}, \mathrm{Cr}, \mathrm{Ni}, \mathrm{Sr}, \mathrm{Ga}$ and $\mathrm{V}$. Field studies indicate that Dokhan volcanics extrude both tonalite-granodiorite and monzogranite with sharp contact forming a thick successive sequence of laminated acid lava flows, crystal lapilli tuffs and agglomerates. They range in composition from rhyolite, rhyodacite to dacite. Shear zone comprise lines-arranged intrusions trending NE-SW direction were recorded north Gabal Hadarba and extends for about 2.3 $\mathrm{km}$ in length with a width reaches up to 10 meter. These lines-arranged intrusions include quartz vein, microgranite and basic dykes. These shear zones cut through monzogranite.

Petrochemical studies and tectonic discrimination diagrams for the monzogranite reveal that it is classified as granite developed in the within-plate tectonic environment, while Dokhan volcanics are classified as rhyolite and dacite developed in the immature island arcs and active continental margin environments. Field radiometric measurements of the granitic and volcanic rocks reveal low uranium and thorium contents. Equivalent uranium content ranges from 1.2 to $2.7 \mathrm{ppm}$ in the tonalite-granodiorite, from 1.1 to $8.5 \mathrm{ppm}$ in the monzogranite, from 1.3 to $9.3 \mathrm{ppm}$ in the Dokhan volcanic and from 1.4 to 15.4 ppm in the felsite dyke.
\end{abstract}

Keywords: Geochemistry, granitic and volcanic rocks, Hadarba area

\section{INTRODUCTION}

The studied area is located in the Southern extremity of the Eastern Desert of Egypt nears the Sudan Frontier and occupies the southern half of Elba topographic sheet (NF-37 I), scale $1: 250,000$. It is easily reached through the Shalatin- Halaib asphaltic road along the Red Sea Coast. It lies at a distance of about $40 \mathrm{~km}$ south of Abu-Ramad City. It is bounded by Latitudes $22^{\circ} 00^{\prime} 00^{\prime \prime}$ to $22^{\circ} 09^{\prime} 53^{\prime \prime} \mathrm{N}$ and Longitudes $36^{\circ}$ $27^{\prime} 50^{\prime \prime}$ to $36^{\circ} 51^{\prime} 04^{\prime \prime} \mathrm{E}$ covering area about 675 $\mathrm{km} 2$.Geomorphologically, the area is characterized by the rough Red Sea mountains, moderate isolated hills, conical low hills, wadi floors and coastal plain (Fig.1). The important mountains encountered in the area are Gabal Hadarba, Gabal Shellal, Gabal Karm Elba and Gabal O Wata and the important wadis are Wadi Shellal and Wadi Aqilhoq.

Hadarba area is underlain mainly by the granitic rocks and Dokhan volcanics. The granitic rocks are represented by tonalite-granodiorite and monzogranite. Dokhan volcanic forms successive sequence of acidic lava flows, ash tuffs, crystal lapilli tuffs and agglomerates. Several studies have been carried out on the petrogra- phy and geochemistry of the Dokhan volcanics, Basta et al., (1980); Stern and Gottfried, (1986); El Gaby et al., (1989); Abdel Rahman, (1996); Mohamed et al., (2000); Eliwa, (2000); Moghazi, (2003); El Sayed et al., (2004); Eliwa et.al (2006); Khalaf (2010) and Alaabed and El Tokhi(2014). These authors show that the Dokhan volcanics have medium- to high-K calcalkaline affinities. The geotectonic interpretation of the Dokhan volcanics is still controversial, especially whether they have been formed (1) in a subduction environment (Hassan and Hashad, 1990; El Gaby et al., 1990),(2) in association with extension after crustal thickening(Stern et al., 1984, 1988; Stern, 1994; Fritz et al.,1996),(3) during transition between subduction and extension (Ressetar and Monard, 1983; Mohamed et al., 2000).

The study area was earlier studied by Ball (1912), studied the topography and geology of the South Eastern Desert, Egypt. Hume (1934) studied the fundamental Precambrian rocks of Egypt and Sudan. Hussein (1977) studied the geology of Halaib area at the northern Red Sea Hills with reference to the Sol Hamed basic complex. Fitches (1983) studied the Late 
Proterozoic ophiolite of Sol Hamed, NE Sudan. El Alfy et.al. (1994) prepared geochemical exploration of Elba - Gerf area South Eastern Desert. Nasr and Youssef (1995) studied the Tertiary alkaline rocks in Gabal Elba area South Eastern Desert. Khaliad et.al. (1997) studied the results of geological, mineralogical and geochemical exploration of Gebel Elba. Nasr and El Sherbeni (1998) studied the Dokhan volcanics in the Halaib area South Eastern Desert. He concluded that a new occurrence of Dokhan volcanics in Halaib area is presented by a thick succession of surface and subsurface acid volcanics. Omar et.al. (1998) prepared geochemical map sheet No. 36 NE L 1,2,3 of Qash Amir area, South Eastern Desert, Egypt. Geological Survey of Egypt (1999) prepared geologic map on scale 1:250.000 for the basement rocks of Gabal Elba Quadrangle, Egypt between Latitude $22^{\circ} 00^{\prime}-23^{\circ} 00^{\prime}$.

The chief aim of the present study is elucidating geology, geochemistry and radioactivity of the granitic and volcanic rocks at Hadarba area, South Eastern Desert, Egypt.

\section{GEOLOGIC SETTING}

The area of study is covered by a succession of Neoproterozoic Pan-African (Precambrian) basement rocks including intrusive and extrusive assemblages. The intrusive rocks comprise tonalite-granodiorite and monzogranite. The extrusive rocks include Dokhan volcanics which are mainly exposed as successive sequences of lava flows, tuffs, and agglomerates, approximately $5 \mathrm{~km}$ thick and constitute moderately high mountainous ridges (Fig.2). These rocks are cut by numerous acidic, intermediate and dolerite dykes.

These rocks include both tonalite-granodiorite and monzogranite.

\section{Tonalite - granodiorite}

Tonalite - granodiorite rocks are widespread rock unites encountered in the area. These rocks are well represented at Wadi Aqilhoq and north Gabal Hadarba. They form NE elongated belts of low to moderate relief, weathered, exfoliated and composed essentially of quartz, plagioclase, K-feldspar, biotiteand minor hornblende.

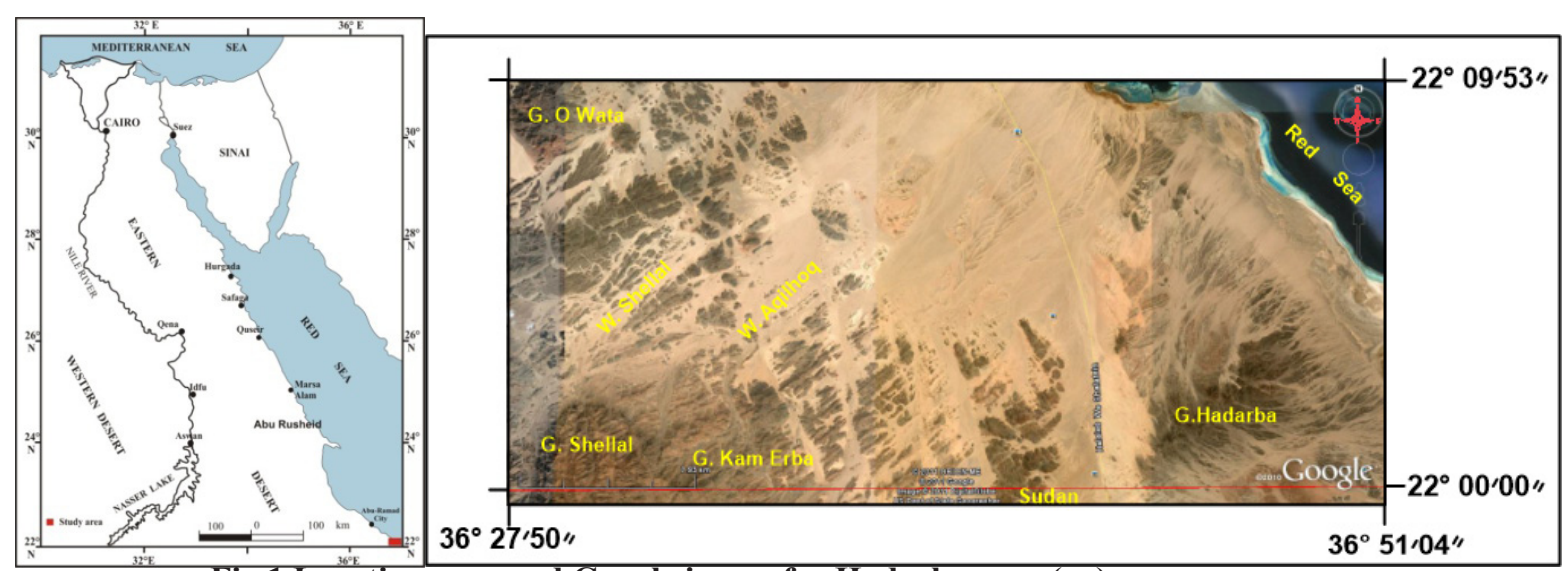

Fig.1 Location map and Google image for Hadarba area ( ).

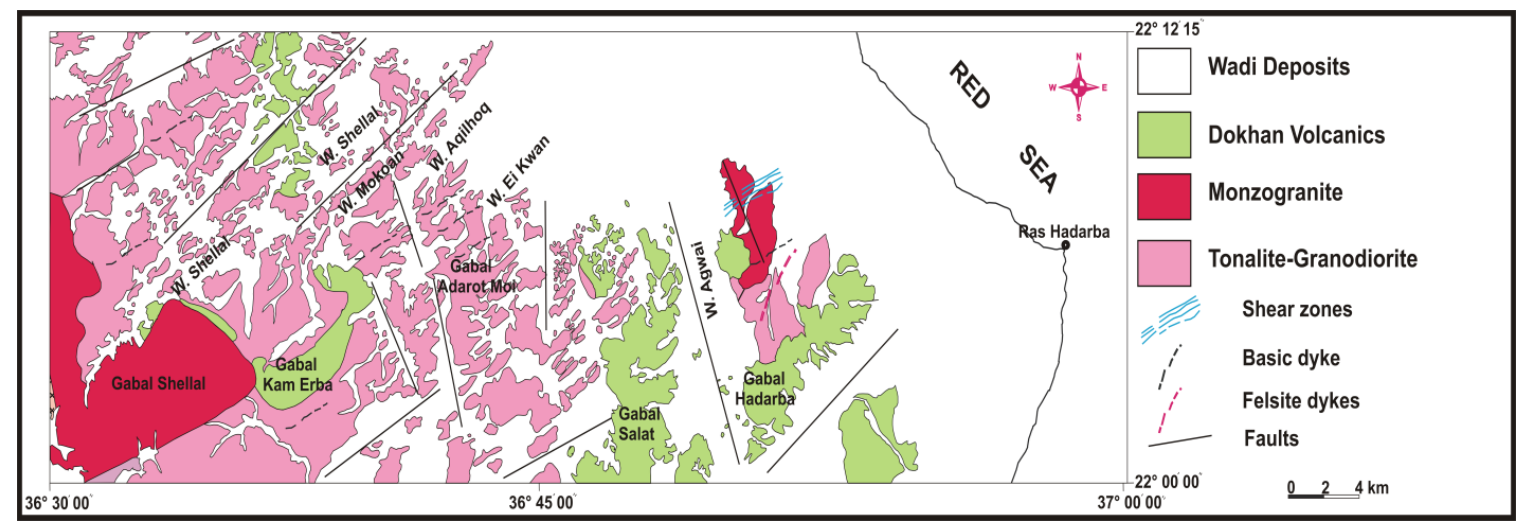

Fig.2.Geologic map for Gabal Hadarba area.Intrusive rocks 
These rock contained subrounded to subangular mafic rich xenolithic bodies up to $20 \mathrm{~cm}$ in diameter (Fig.3A\&B). These rocks are extruded by Dokhan volcanics and intruded by monzogranite. The tonalite-granodiorite are invaded by dyke swarms trending E-W and NW-SE mainly of felsite and rhyolite porphyry.

\section{Monzogranite}

The monzogranite granite well represented as low, moderate and high hills at Gabal Shellal and north Gabal Hadarba(Fig.3C).This rock is pale pink to pink color; medium to coarse grained and composed of quartz, K-feldspar,biotite and rare muscovite. Field study indicates that the monzogranite intrudes tonalite-granodiorite and extruded by Dokhan volcanics and cross cut by swarms of felsite and acidic dykes (Fig.3D).

\section{Extrusive rocks}

They are represented by Dokhan volcanics.

\section{Dokhan volcanics}

Dokhan volcanics are widely distributed and exposed as nearly N-S elongated belts at Hadarba area, which occupy a large area at Wadi Hibru, Wadi Kuwan, Gabel Hadarba and Wadi
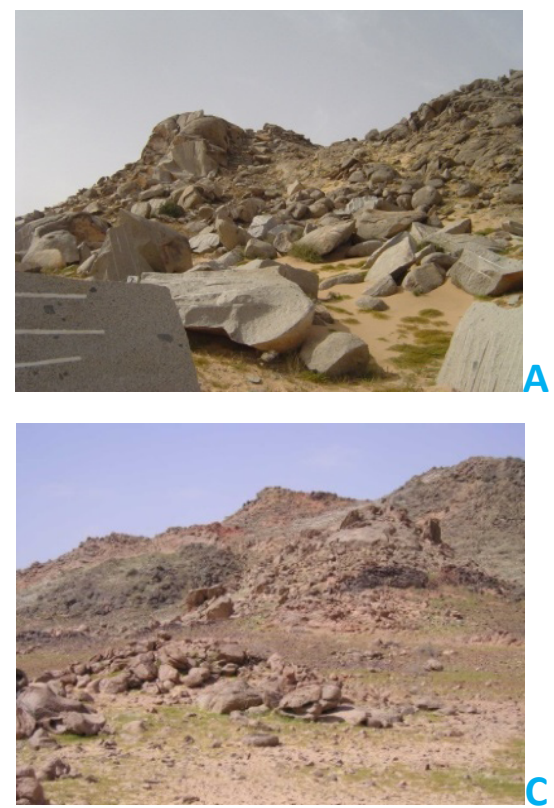

Aqilhoq. These rocks are represented by successive sequences of lava flows, tuffs, and agglomerates (Fig.4A-F). In some parts these sequences are emplaced as subhorizontal successive sheets of volcanic porphyry which are concordant to the banding. The successive lava flow ranges in composition from rhyolite, rhyodacite to dacite, as well as thick sequences of welded ash flow tuffs, crystal tuffs, lithic lapilli tuffs and agglomerates. Porphyritic texture is well developed in the most of these rocks. Field study indicates that Dokhan volcanics are extruded in the tonalite-granodiorite and monzogranite as well as felsite, acidic and basic dyke swarms (Fig. 4F). These volcanic rocks are relating to the Feirani volcanics of the South Sinai Egypt by Abu ElLeil et al., (1990).

\section{Hadarba shear zones}

Hadarba shear zones comprise line-arranged intrusions trending to the NE-SW direction and extend for about $2.3 \mathrm{~km}$ length with a width reaching up to 6 to 10 meters for each one (Fig.5A\&B).

These line-arranged intrusions include microgranite dyke, basic dyke and quartz vein
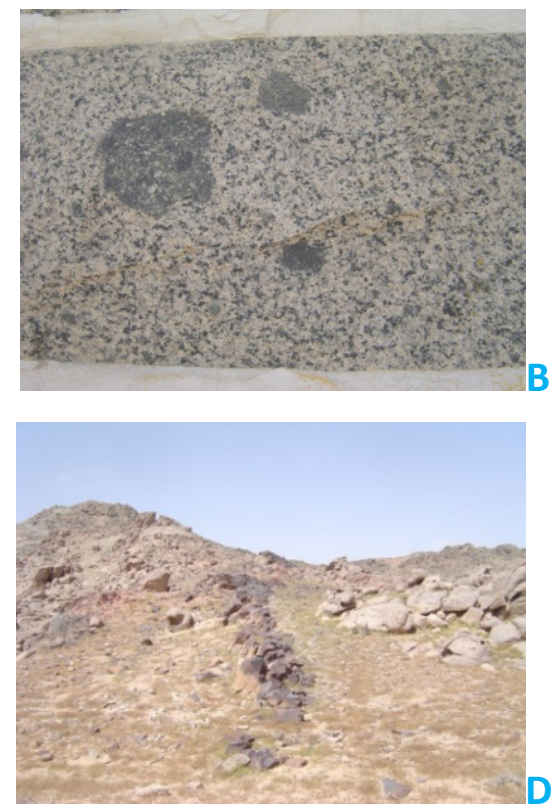

Fig.3 Field Photographs for granitoid rocks,

A. Blocks of tonalite-granodiorite in Hadarba quarry. Looking W

B. Close view showing subrounded mafic rich xenoliths in tonalite-granodiorite. Looking $S$

C. Photograph showing monzogranite granite extruded by Dokhan volcanics. Looking SE

D. Photograph showing felsite dyke cutting in monzogranite. Looking $\mathrm{S}$ 
cut through monzogranite (Fig.6). The quartz veins are cutting through the monzogranite in NE-SW direction. It is precipitated as massive, milky quartz and in some parts it is a fractured and jointed. Their thickness ranges from 5 to 10 meters and extends for about 900 meters length. This quartz veins have uranium content range from $0.2-0.8 \mathrm{ppm}$. The microgranite dykes are mainly injected along the NE-SW direction. These dykes are whitish buff to buff in color, leucocratic, fine grained, massive and equigranular texture. The thickness of these dykes varies from $1 \mathrm{~m}$ to $6 \mathrm{~m}$ and extends for more than $2300 \mathrm{me}-$ ters in the NE-SW direction. These dykes have uranium content ranges from 1.9 to $4.6 \mathrm{ppm}$.

Basic dykes follow the main fault plain with nearly vertical dip. They extend along the NESW shear zone for more than $2.3 \mathrm{~km}$ long with

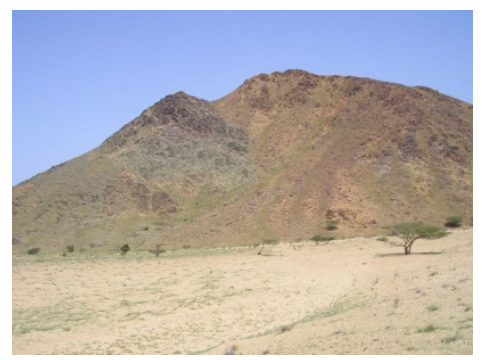

A
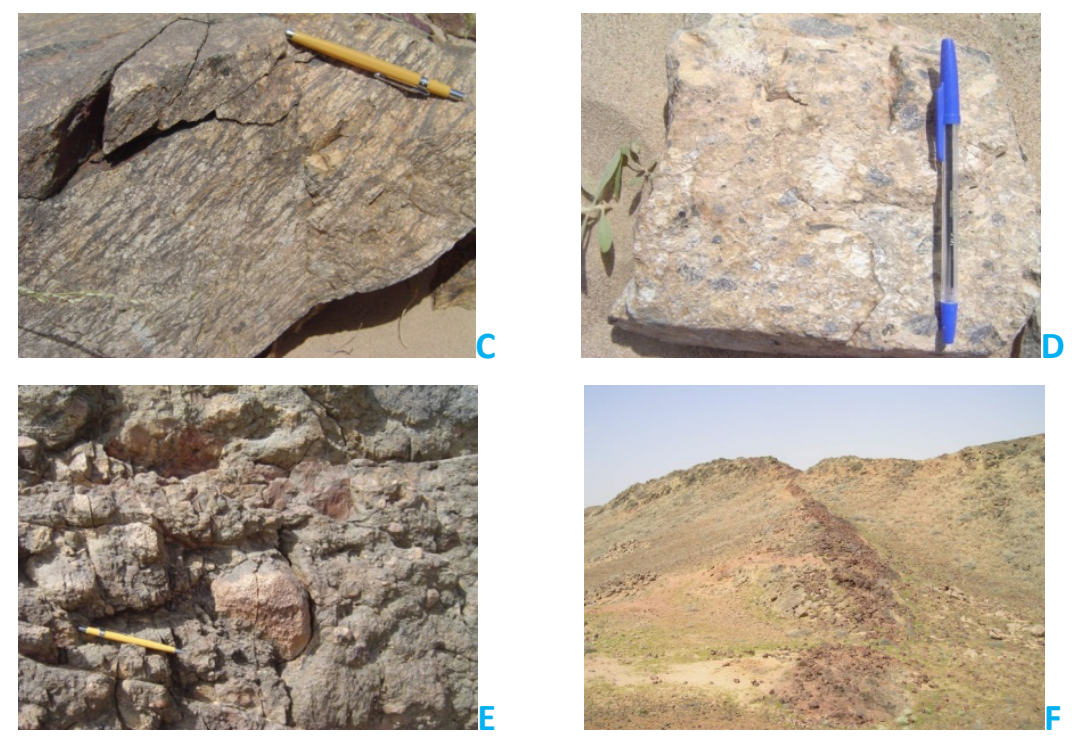
content ranges from 0.3-4.4 ppm.

\section{PETROGRAPHY}

\section{Tonalite - granodiorite}
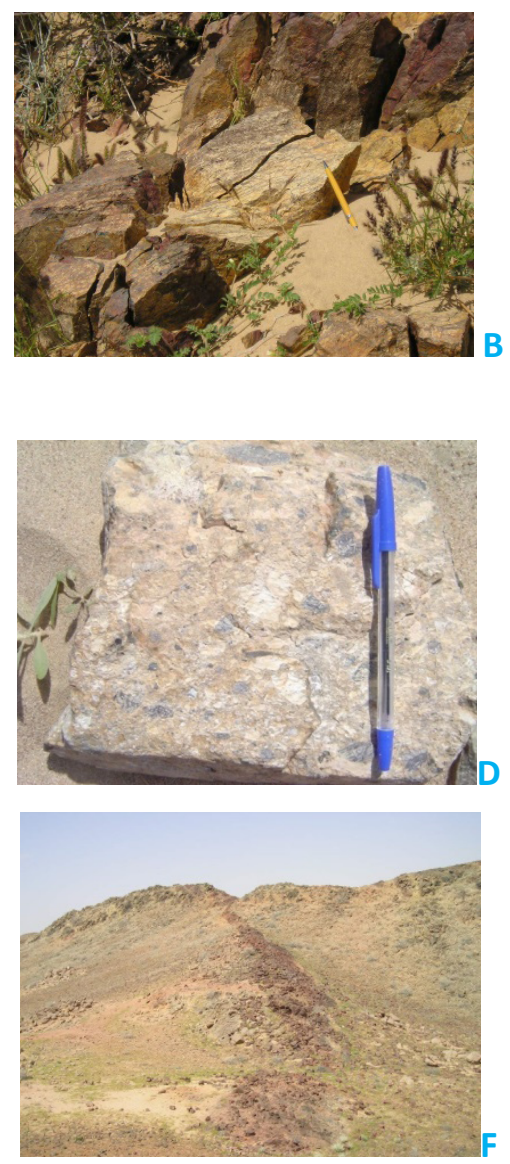

Fig.4 Field Photographs for Dokhan volcanics,
A. Sequences of buff and violet rhyolite. Looking W
B. Laminating acid lava flows. Looking SW
C.Close view showing rhyolite follow band.
D. Crystal lapilli tuffs in Dokhan volcanics.
E. Large enclave of granitic composition in agglomerate rock. Looking SW
F. Felsite dyke extruding in Dokhan volcanics. Looking W

width varies from $1 \mathrm{~m}$ to $8 \mathrm{~m}$. They are dark gray to grayish green color, fine grained and composed essentially of plagioclase, amphibole, chlorite and epidote. These dykes have uranium

They are distinctly equigranular, coarsegrained of hypidiomorphic texture. Microscopically, they are composed mainly of plagioclase, quartz, alkali feldspar and hornblende. The accessory minerals are apatite, sphene and iron oxides. Plagioclase represents the main constituent mineral in these rocks. It is represented by euhedral megacrysts up to $3.4 \times 2.1 \mathrm{~mm}$. Polysynthetic twinning and zoned plagioclase are well common (Fig.7A). Some crystals show defor- 


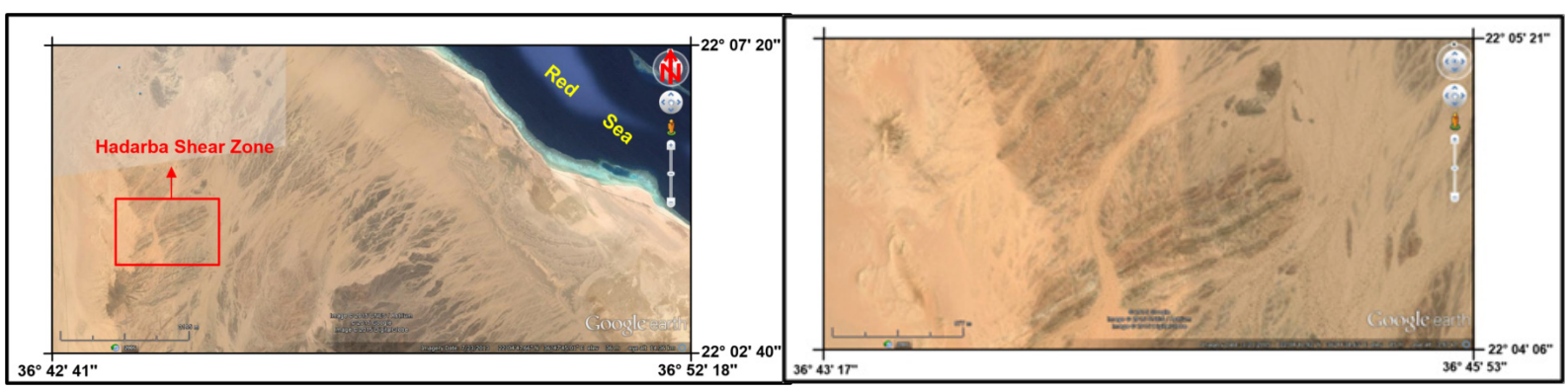

Fig.5A General view Google image for Hadarba shear zone.

Fig. 5B Close up view Google image for Hadarba shear zone.

mation due to outer stress (Fig.7B). Quartz occurs as anhedral phenocrysts up to $5 \times 4.6 \mathrm{~mm}$. All quartz crystals are characterized by the wavy extinction due to outer stress and deformation. Alkali feldspar occurs as euhedral to subhedral

megacrysts up to $2.3 \times 1.3 \mathrm{~mm}$. Most of these alkali feldspar crystals are represented by perthite, where perthite veinlets are observed. Hornblende occurs as subhedral to anhedral megacrysts up to $1.1 \times 0.6 \mathrm{~mm}$. It also occurs as small crystals filling the spaces between the plagioclase megacrysts. Most of the hornblende megacrysts enclose metamict zircon (Fig.7C).

\section{Monzogranite}

They are distinctly equigranular medium to coarse grained of hypidiomorphic texture. Microscopically, they are composed essentially of quartz, perthite, plagioclase, biotite and rare muscovite. The accessory minerals are iron oxides, apatite and zircon. Quartz occurs either as subhedral to anhedral megacrysts up to $4.8 \times 3.9$ $\mathrm{mm}$ or as small crystals up to $0.1 \times 0.2 \mathrm{~mm}$. It is found in two generation, the older fills the interstices between the feldspar crystals, whereas the younger is graphically intergrowth with perthite crystals. Perthite occurs as subhedral megacrysts up to $2.6 \times 3.3 \mathrm{~mm}$. Perthitic veinlets are the most predominate type of perthite in these rocks (Fig.7D). Biotite represents the chief mafic minerals. It occurs as subhedral to anhedral crystals. These biotite crystals show pleochroism from yellow to brown color. Biotite megacrysts reach up to $1.35 \times 0.6 \mathrm{~mm}$, while the small crystals up to $0.3 \times 0.25 \mathrm{~mm}$. They are variably altered to chlorite (Fig.7E).

\section{Dokhan volcanics}

\section{Rhyolite}

Rhyolite shows mainly porphyritic textures (Fig.8A\&B). It is formed essentially by phenocrysts of quartz, plagioclase and potash feldspars (saindine) embedded in a fine-grained groundmass of quartz and, sanidine .Chlorite, sericite and epidoteare secondary mineral, whereas zircon and iron oxides are accessories.

\section{Rhyodacite-dacite}

Rhyodacite-dacite shows flow structures and banding. These rocks contain phenocrysts of quartz plagioclase, sanidine embedded in microcrystalline groundmass of quartz, plagioclase, sanidine and hornblende. Chlorite and epidote occur as alteration minerals, the accessory minerals are zircon, apatite and iron oxides(Fig.8C).

\section{Lithic lapilli tuffs}

These rocks are composed of lithic and crystal fragments embedded in a fine grained ground-

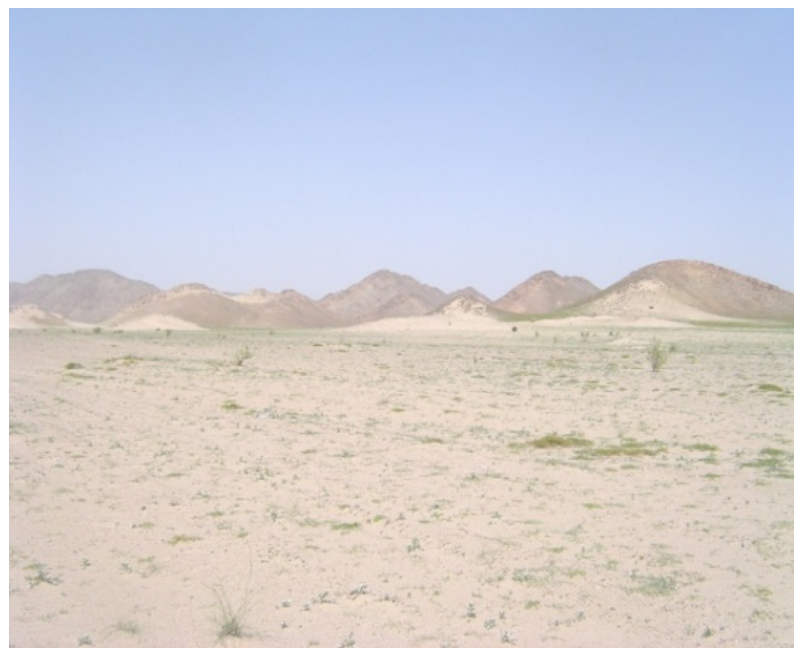

Fig.6 Line-arranged intrusions include microgranite, basic dykes and quartz vein at Hadarba Shear zone. 
mass of plagioclase, orthoclase and quartz. The crystals are formed of feldspar and quartz while the lithic fragments are made of rhyodacite and dacite porphyry (Fig.8D).
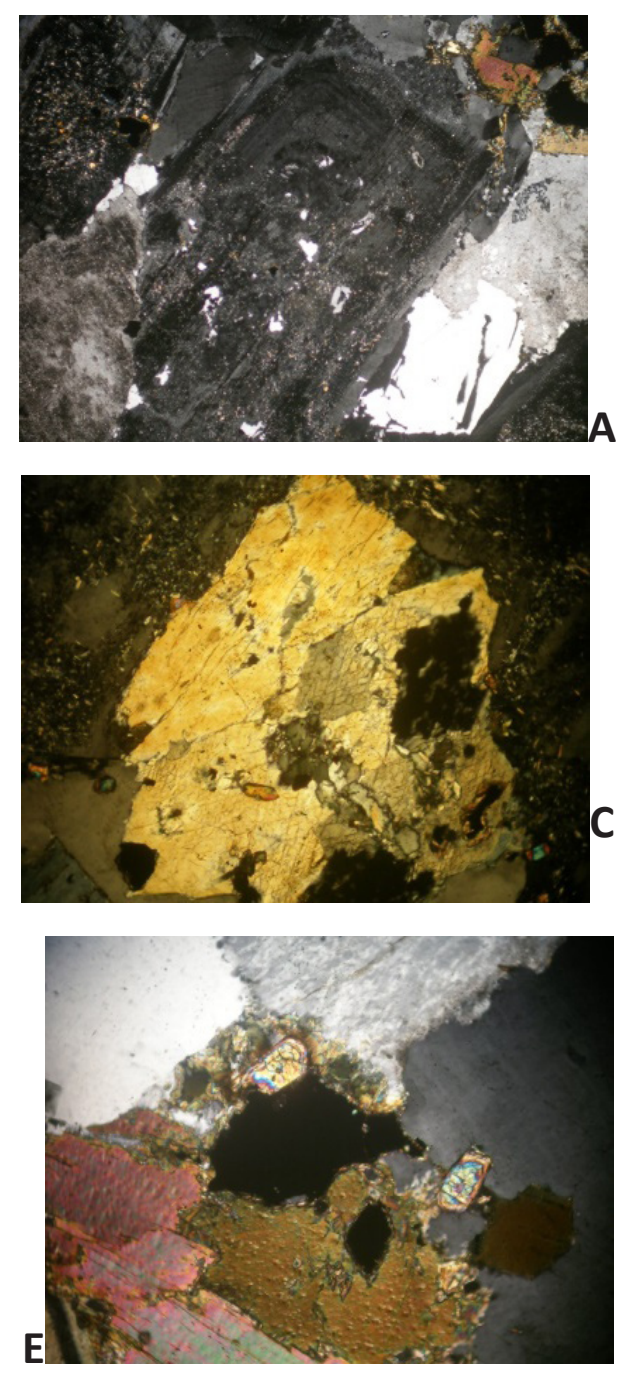

\section{Crystal tuffs}

They are consists of quartz and plagioclase phenocrysts set in a fine grained groundmass composed of plagioclase and quartz (Fig.8E).
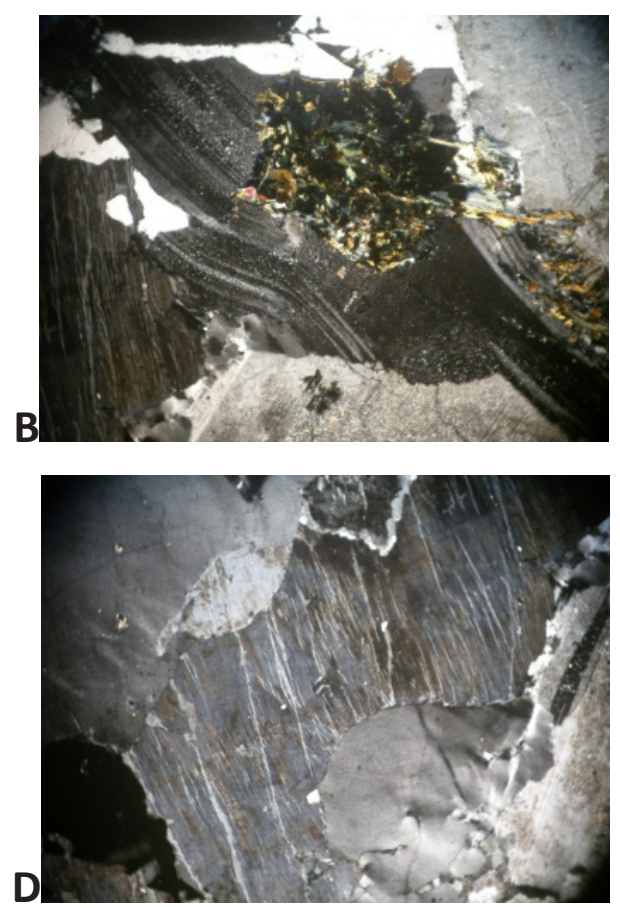

Fig.7Microscopic investigation of the studied granitoid rocks,

A. Plagioclase exhibiting zonal structure in tonalite-granodiorite, C.N. X10

B. Chlorite and eipdote inclusion in folded plagioclase in tonalitegranodiorite, C.N. X20

C. Hornblende enclosed zircon in tonalite-granodiorite, C.N. X20

D. String perthite corroded by quartz in monzogranite, C.N. X20

E. Metamict zircon associated with perthite and biotite in monzogranite, C.N. X40
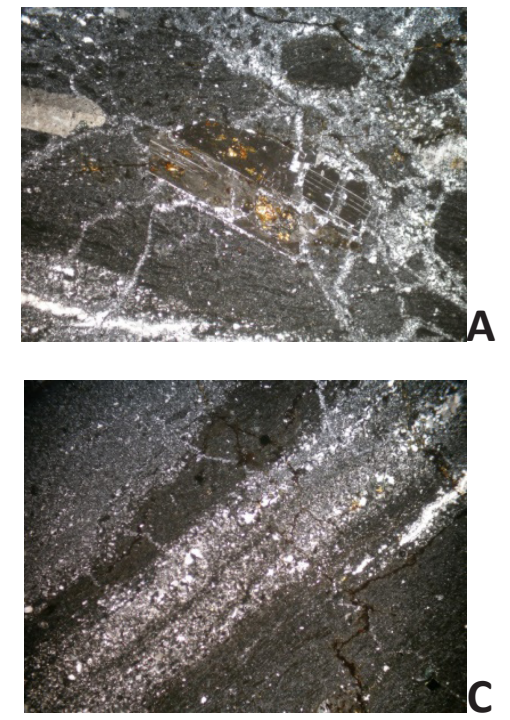
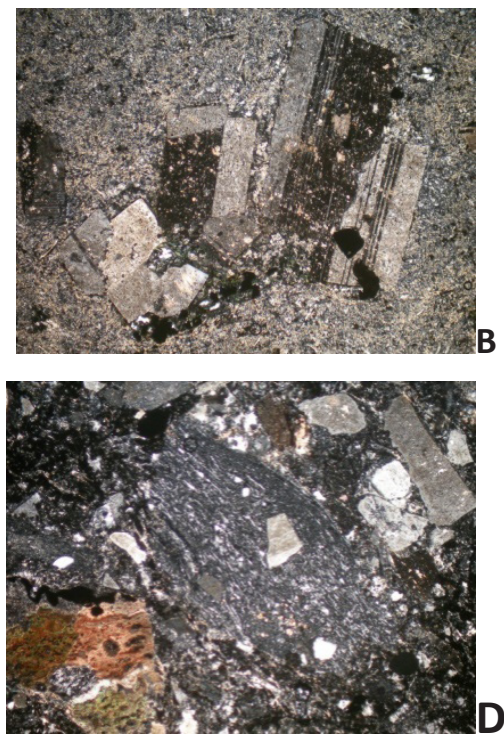

Fig.8Microscopic investigation of the studied Dokhan volcanics,

A.\&B. Porphyroblasts of plagioclase in crystal lapilli tuffs, C.N. X10

C. Flow banding in rhyodacitedacite C.N. X20

D. Lithic and crystal fragments embedded in fine grained groundmass, C.N. X20 


\section{Agglomerate}

Agglomerate is large, coarse, rock fragments associated with lava flow. These rock fragments are composed of granitic rocks of various sizes and degrees of angularity.

\section{RADIOMETRIC INVESTIGATION}

Regional field radiometric measurements revealed that the eU reaching up to $2.7 \mathrm{ppm}$ in the tonlaite-granodiorite, up to $8.5 \mathrm{ppm}$ in the monzogranite, up to $9.3 \mathrm{ppm}$ in the Dokhan volcanics, while reaching up to $15.4 \mathrm{ppm}$ in the felsite dykes. The statistical treatment of spectrometric data was expressed on binary diagrams of eTh versus eU, eU versus eU/eTh and eU versus eUeTh/3.5 (Fig.9).These figures indicate that the tonlaite-granodiorite, monzogranite and Dokhan volcanic show low uranium content except the felsite dyke which shows slightly high uranium content. Radiometric data for tonlaite-granodiorite, monzogranite, Dokhan volcanics, microgranite dykes and felsite dyke are listed in Table (1).

\section{MATERIALS AND METHODOLOGY}

Thirty samples from the best exposures of the granitic and volcanic rocks from Hadarba area were collected for this study. From these, 21 samples were selected for thin sections to study the mineral constituents of this granite and Dokhan volcanics. Four samples of the monzogranite granite and five samples of the Dokhan volcanic were selected and chemically analyzed for their major oxides and trace elements. The trace elements were analyzed by X-ray fluorescence analyzer (XRF). The analyses were per-

Table1. Radiometric measurements data for the studied granitic, Dohkan volcanics and the associated dykes at Hadarba area.

\begin{tabular}{|c|c|c|c|c|c|c|c|c|c|c|c|c|}
\hline \multirow{2}{*}{ Rock type } & \multicolumn{3}{|c|}{ Total Count } & \multicolumn{3}{|c|}{ K (\%) } & \multicolumn{3}{|c|}{ eU(ppm) } & \multicolumn{3}{|c|}{ eTh(ppm) } \\
\hline & Min. & Max. & Aver. & Min. & Max. & Aver. & Min. & Max. & Aver. & Min. & Max. & Aver. \\
\hline $\begin{array}{c}\text { Tonlaite- } \\
\text { granodiorite } \\
(\mathbf{N}=\mathbf{8 5})\end{array}$ & 12.2 & 19.8 & 15.4 & 2.1 & 2.7 & 2.4 & 1.2 & 2.7 & 1.4 & 5.8 & 8.8 & 7.3 \\
\hline $\begin{array}{l}\text { Monzogranite } \\
(\mathrm{N}=121)\end{array}$ & 6.3 & 28 & 17.7 & 1 & 4.9 & 3.41 & 1.1 & 8.5 & 3.46 & 1.3 & 13.3 & 7.6 \\
\hline $\begin{array}{c}\text { Dokhanvolcanics } \\
(\mathrm{N}=111)\end{array}$ & 2.4 & 43.2 & 20.21 & 0.6 & 10.1 & 4.32 & 1.3 & 9.3 & 3.79 & 0.5 & 14.3 & 7.1 \\
\hline $\begin{array}{c}\text { Microgranite } \\
\text { dyke(N=65) }\end{array}$ & 8.5 & 22.2 & 15.35 & 2.5 & 4.9 & 3.7 & 1.9 & 4.6 & 3.25 & 3.9 & 12.1 & 8 \\
\hline $\begin{array}{c}\text { Felsite dyke } \\
(\mathrm{N}=73)\end{array}$ & 8.5 & 49.1 & 34.31 & 1 & 6.5 & 4.92 & 1.4 & 15.4 & 8.24 & 3.9 & 32.5 & 18.6 \\
\hline Basic dyke $(\mathrm{N}=90)$ & 2.4 & 4.4 & 3.4 & 0.8 & 1 & 0.9 & 0.3 & 4.4 & 2.35 & 0.4 & 2.1 & 1.3 \\
\hline $\begin{array}{c}\text { Quartz vein } \\
(N=65)\end{array}$ & 3.2 & 5.2 & 4.2 & 0.8 & 1.3 & 1.05 & 0.2 & 0.8 & 0.5 & 0.3 & 2.3 & 1.3 \\
\hline
\end{tabular}
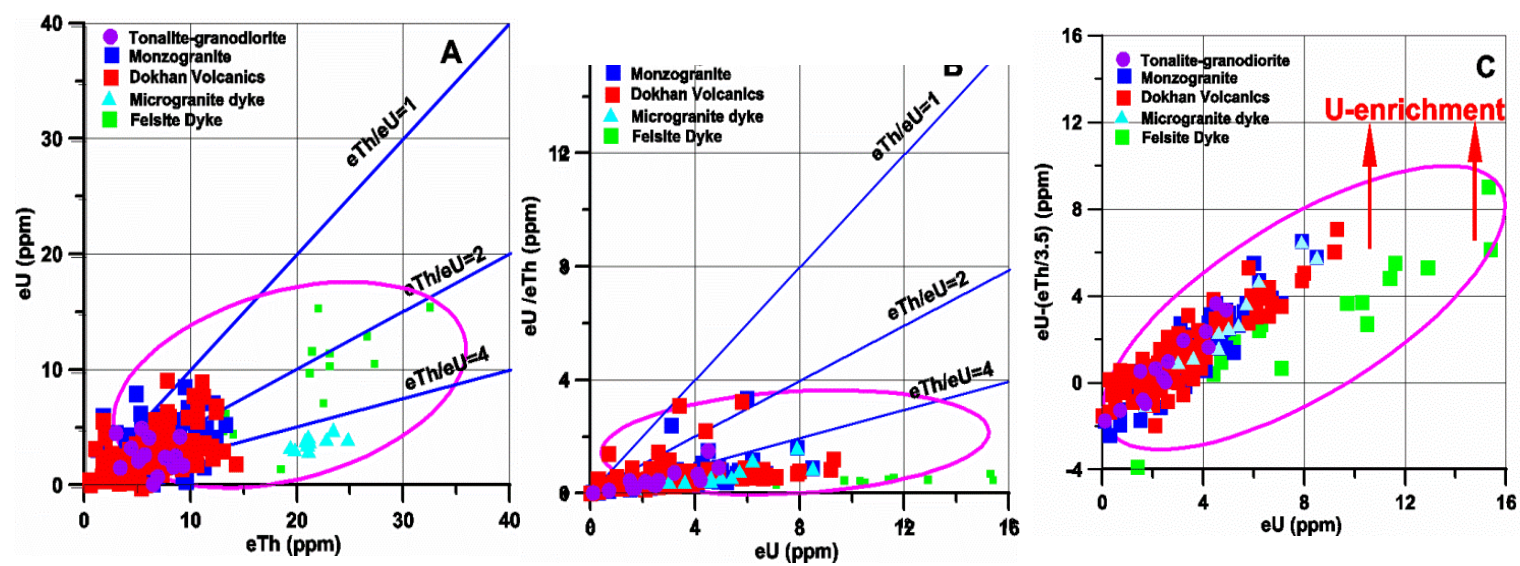

Fig.9 Radioactive elements plot for ground gamma-ray spectrometry measurements for the studied tonalite-granodiorite, monzogranite, Dokhan volcanics, microgranite dyke and felsite dyke A. eTh versus eU, B.eU versus eU/eTh and C. Mobility. 
formed in the Nuclear Materials Authority Analytical Laboratories. Data of the major oxides and trace elements are listed in Table (2).

\section{GEOCHEMISTRY}

The geochemistry of the studied area is focused mainly on the monzogranite and the Dokhan volcanics of the Hadarba area to clarify their chemical classification, chemical affinity, magma type and tectonic setting.

\section{Chemical classification}

The classification of the studied monzogranite and the Dokhan volcanic were chemically confirmed by plotting the analyses on $\mathrm{SiO}_{2}$ versus alkalis diagrams after Middlemost, (1985) and $\mathrm{Cox}$ et al.,(1979) (Figs.10\&11). On $\mathrm{SiO}_{2}$

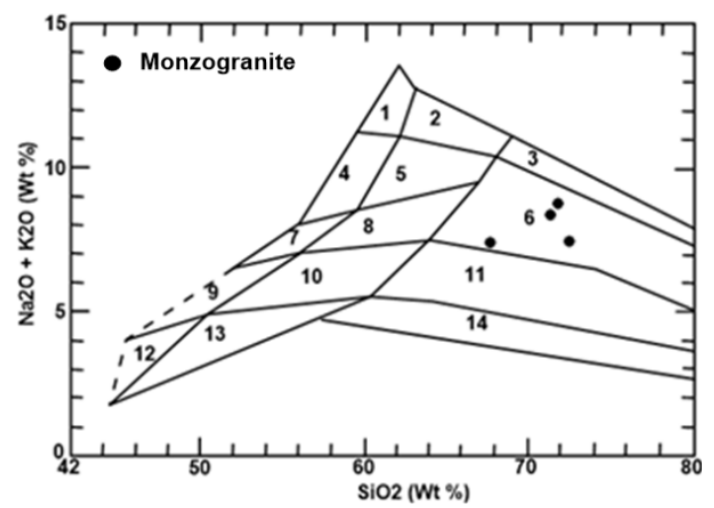

Fig.10 $\mathrm{SiO} 2$ versus alkalis diagram for the studied monzogranite after Middlemost (1985). Granite field (6).

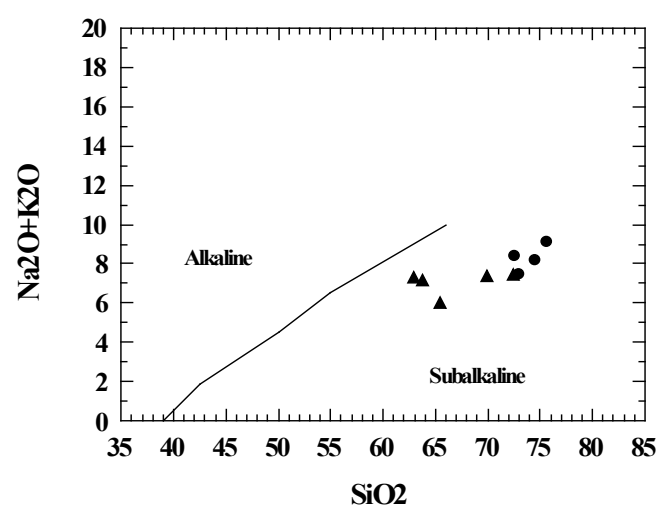

Fig.12 $\mathrm{SiO}_{2}$ versus $\mathrm{Na}_{2} \mathrm{O}+\mathrm{K}_{2} \mathrm{O}$ diagrams for studied monzogranite and the Dokhan volcanics, after Irvine and Baragar (1971). versus alkalis diagram after Middlemost, (1985) the monzogranite samples fall in the granite field, while on $\mathrm{SiO}_{2}$ versus alkalis diagram after Cox et al., (1979) the Dokhan volcanics samples fall in the rhyolite and dacite fields.

\section{Alkaline affinity}

In the $\mathrm{SiO}_{2}$ versus $\mathrm{Na}_{2} \mathrm{O}+\mathrm{K}_{2} \mathrm{O}$ diagram (Fig. 12), after Irvine and Baragar (1971) all the monzogranite and the Dokhan volcanic samples show subalkaline affinity.

\section{Tectonic setting}

On the $\mathrm{Y}$ versus $\mathrm{Nb}$ diagram (Fig. 13), after Pearce et al. (1984) the monzogranite samples fall in the within plate granites (WPG) field, while Dokhan volcanic samples fall in the volcanic arc granite

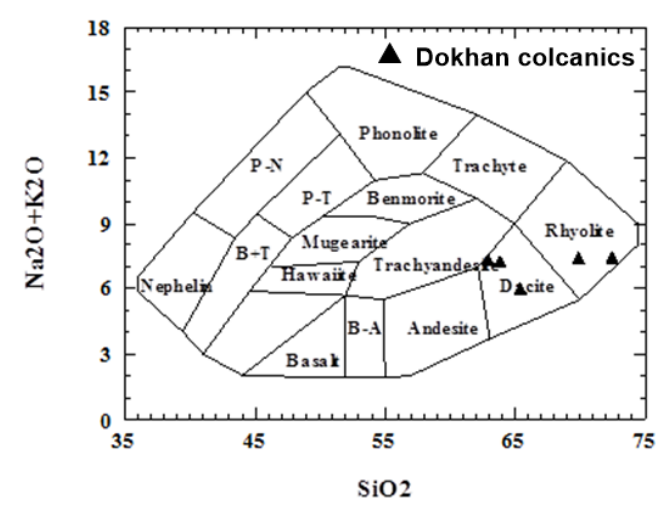

Fig.11: SiO2 versus alkalis diagram for the studied Dokhan volcanics after Cox et al. (1979).

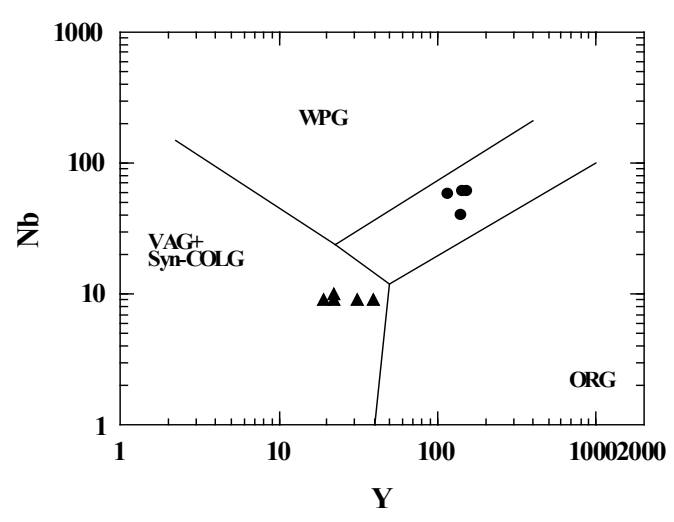

Fig.13Nb - Y tectonic discrimination diagram for the studied monzogranite and Dokhan volcanics, Syn-collision (Syn- COLG),volcanic arc granites ( VAG ), within plate granites ( WPG ) and ocean ridge granites ( ORG ), after Pearce et al. (1984). 
Table2. Major oxides (\%) and trace element contents (ppm) of the studied monzogranite and Dokhan volcanics.

\begin{tabular}{|c|c|c|c|c|c|c|c|c|c|}
\hline \multirow[b]{2}{*}{ S. No. } & \multicolumn{4}{|c|}{ Monzogranite } & \multicolumn{5}{|c|}{ Dokhan volcanics } \\
\hline & 14 & 15 & 27 & 40 & 4 & 5 & 6 & 9 & 37 \\
\hline $\mathrm{SiO}_{2}$ & 75.66 & 74.55 & 72.57 & 73.01 & 72.44 & 63.83 & 62.90 & 65.39 & 69.91 \\
\hline $\mathrm{TiO}_{2}$ & 0.21 & 0.18 & 0.20 & 0.18 & 0.35 & 0.88 & 0.45 & 0.12 & 0.42 \\
\hline $\mathrm{Al}_{2} \mathrm{O}_{3}$ & 12.48 & 12.60 & 12.58 & 12.37 & 12.18 & 12.64 & 13.95 & 13.90 & 12.01 \\
\hline $\mathrm{Fe}_{2} \mathrm{O}_{3}$ & 1.26 & 1.59 & 3.39 & 2.99 & 4.50 & 9.18 & 5.79 & 8.65 & 5.07 \\
\hline MnO & 0.02 & 0.06 & 0.04 & 0.03 & 0.10 & 0.11 & 0.40 & 0.18 & 0.15 \\
\hline MgO & 0.40 & 0.71 & 0.40 & 0.81 & 0.60 & 1.61 & 1.01 & 0.50 & 0.81 \\
\hline $\mathrm{CaO}$ & 0.68 & 1.66 & 1.68 & 1.96 & 1.68 & 4.21 & 2.80 & 2.40 & 3.36 \\
\hline $\mathrm{Na}_{2} \mathrm{O}$ & 4.25 & 4.75 & 4.95 & 3.79 & 1.85 & 5.59 & 5.05 & 0.61 & 4.85 \\
\hline $\mathrm{K}_{2} \mathrm{O}$ & 4.83 & 3.45 & 3.45 & 2.64 & 5.59 & 1.61 & 2.24 & 5.42 & 2.57 \\
\hline $\mathbf{P}_{2} \mathbf{O}_{5}$ & 0.07 & 0.08 & 0.11 & 0.05 & 0.04 & 0.16 & 0.14 & 0.26 & 0.14 \\
\hline LOI & 0.14 & 0.37 & 0.60 & 2.20 & 0.67 & 0.17 & 5.27 & 2.25 & 0.71 \\
\hline Total & 100.0 & 100.0 & 99.97 & 100.03 & 100.0 & 99.99 & 100.0 & 99.67 & 100.0 \\
\hline \multicolumn{10}{|c|}{ Trace elements (ppm) } \\
\hline $\mathrm{Cr}$ & 71 & 41 & 27 & 34 & 22 & 8 & 12 & 20 & 13 \\
\hline $\mathbf{N i}$ & 7 & 6 & 4 & 6 & 4 & 6 & 4 & 3 & 3 \\
\hline $\mathbf{v}$ & u.d & 4 & 7 & 5 & 7 & 132 & 32 & 4 & 48 \\
\hline $\mathrm{Cu}$ & 10 & 7 & 19 & 8 & 15 & 14 & 16 & 19 & 20 \\
\hline $\mathrm{Pb}$ & u.d & u.d & 11 & u.d & 39 & 87 & 51 & u.d & u.d \\
\hline $\mathrm{Zn}$ & 74 & 46 & 20 & 41 & 67 & 145 & 140 & 28 & 124 \\
\hline $\mathbf{R b}$ & 112 & 86 & 97 & 95 & 116 & 44 & 73 & 201 & 60 \\
\hline $\mathrm{Ba}$ & 144 & 278 & 224 & 592 & 230 & 581 & 421 & 126 & 375 \\
\hline $\mathrm{Sr}$ & 6 & 7 & 321 & 5 & 884 & 894 & 1449 & 1807 & 747 \\
\hline $\mathrm{Ga}$ & 22 & 25 & 24 & 22 & 23 & 22 & 22 & 22 & 23 \\
\hline $\mathrm{Nb}$ & 61 & 61 & 13 & 10 & 10 & 9 & 9 & 9 & 9 \\
\hline $\mathrm{Zr}$ & 215 & 227 & 112 & 172 & 308 & 286 & 451 & 586 & 254 \\
\hline$Y$ & 145 & 153 & 8 & 117 & 22 & 22 & 31 & 39 & 19 \\
\hline
\end{tabular}

u.d = under limit of detection

( VAG ) and syn-collision granite (Syn-COL G) .

Ewart (1979 and 1981) suggested various discrimination diagrams to identify the modern tectonic environments (Fig. 14). The plots of studied Dokhan volcanic samples on $\mathrm{SiO}_{2}$ versus $\mathrm{Zr}$ binary diagram indicate that, most samples fall within immature island arcs field except one sample occurs in the active continental margin field.

\section{Trace elements}

In primitive-mantle normalized spidergrams (Fig. 15), the monzogranite samples are enriched in some LILE (large ion lithophile elements)
$(\mathrm{Rb}, \mathrm{Sr}, \mathrm{Ba}, \mathrm{K})$ and HFSE (high field strength elements) ( $\mathrm{Zr}, \mathrm{Y}, \mathrm{Nb}$ ), but strongly depleted in $\mathrm{Ni}, \mathrm{Cr}$ andPb.

Relative to normal mid-ocean ridge basalts (N-MORB), the studied Dokhan volcanics (Fig. 16) show enrichment in the strongly incompatible LILE (large ion lithophile elements) such as $\mathrm{Rb}, \mathrm{Ba}$, and $\mathrm{Sr}$ and HFSE (high field strength elements) such as $\mathrm{Zr}$, Y, but strongly depletion in $\mathrm{Nb}, \mathrm{Ni}, \mathrm{Cr}$ and $\mathrm{Pb}$.

\section{CONCLUSION}

Granitic and volcanic rocks are widely occurring at Hadarba area. The granitic rocks comprise tonalite-granodiorite and monzogranite, while 


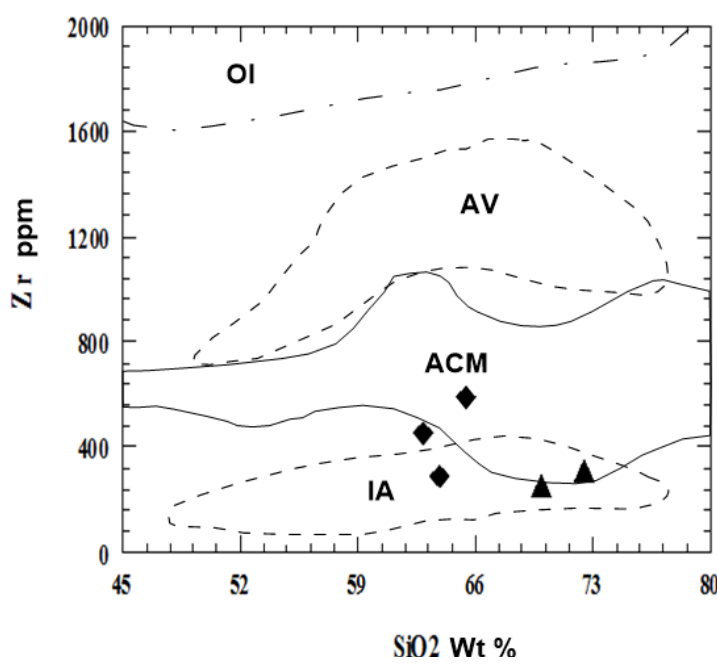

Figure14. $\mathrm{SiO} 2-\mathrm{Zr}$ binary diagram for the studied Dokhan volcanics, after Ewart (1979 \& 1981). $\mathrm{OI}=$ Oceanic islands, $A V=$ Anorogenic volcanic terrains, $\mathrm{ACM}=$ Active continental margins, $\mathbf{I A}=$ Immature island arcs. Symbols as in Fig. (8).

volcanic rocks include Dokhan volcanics which composed of rhyolite, rhyodacite and dacite. Field studies indicate that Dokhan volcanics extrude both tonalite-granodiorite and monzogranite with sharp contact forming a thick successive sequence of laminated acid lava flows, crystal lapilli tuffs and agglomerates. They have composition range from rhyolite, rhyodacite to dacite. These rocks are characterized by high concentrations of $\mathrm{SiO}_{2}, \mathrm{Na}_{2} \mathrm{O}, \mathrm{Fe}_{2} \mathrm{O}_{3}, \mathrm{~K}_{2} \mathrm{O}, \mathrm{Zr}, \mathrm{Nb}$ and $\mathrm{Y}$ but low in $\mathrm{MgO}, \mathrm{CaO}, \mathrm{Cr}, \mathrm{Ni}, \mathrm{Sr}, \mathrm{Ga}$ and $\mathrm{V}$. Shear zone comprises line-arranged intrusions trending NE-SW direction and extends for about $2.3 \mathrm{~km}$ length with a wide reaches up to 6 to 10 meters was found cutting in the mozogranite. The spectrometric measurements reveal low uranium content. Petrochemical studies and tectonic discrimination diagrams for the monzogranite reveal that it is classified as granite developed in the within-plate tectonic environment, while Dokhan volcanics are classified as rhyolite and dacite developed in the immature island arcs and active continental margin environments.

Field radiometric measurements of these granitic and volcanic rocks reveal low uranium and

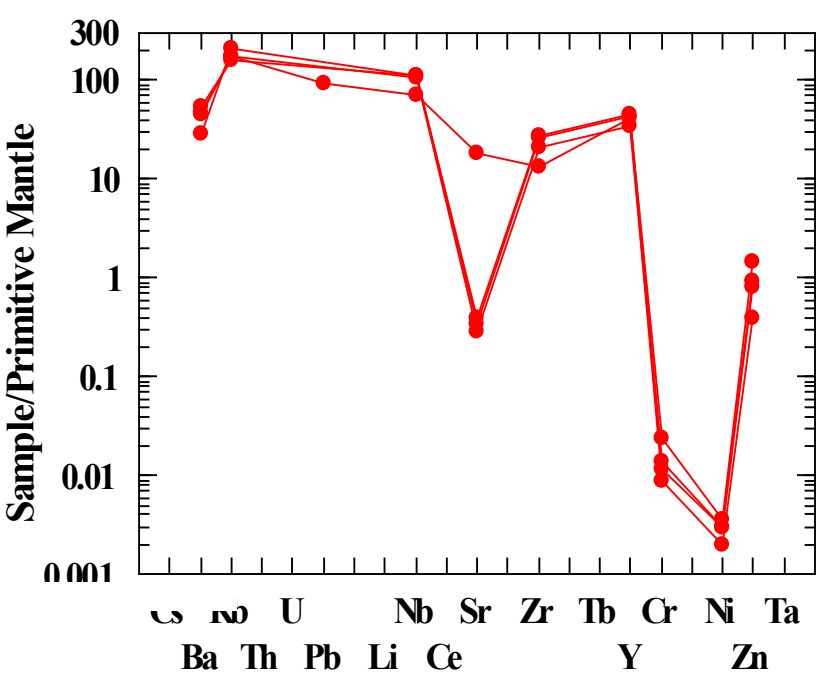

Fig.15Primitive-mantle (PM) normalized spidergram for the studied monzogranite. The PM values are from Sun and McDonough (1989).

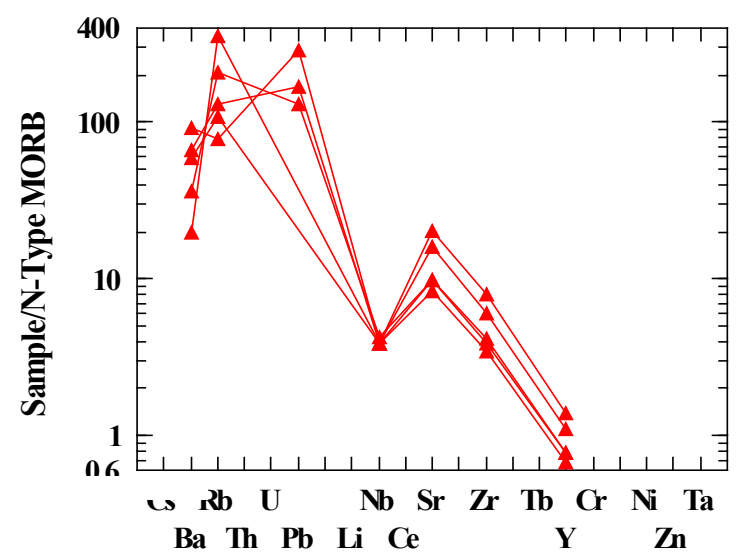

Fig.16 N-MORB-normalized spidergram for the studied Dokhan volcanics.

thorium contents. Uranium contents range from 1.2 to $2.7 \mathrm{ppm}$ in the tonalite-granodiorite, from 1.1 to $8.5 \mathrm{ppm}$ in the monzogranite and from 1.4 to $15.4 \mathrm{ppm}$ in the felsite dyke.

\section{REFERENCES}

Abdel Rahman A.M. (1996): Pan-African volcanism: petrology and geochemistry of the Dokhan Volcanic suite in the northern Nubian Shield. Geol Mag 133:17-31.

Alaabed, S. and El Tokhi, M. (2014):Mineralogical and geochemical aspects of the petrogenesis of Pan African Dokhan volcanics at Esh El Mellaha Area-NE Desert, Egypt. Arabian Journal of Geosciences, Vol. 7, issue 12 , pp 5553-5568. 
Ball, J. (1912): The geography and geology of south eastern Egypt. Geol. Surv., Cairo P. 394.

Basta EZ, Kotb H, Awadalla MF (1980): Petrochemical and geochemical characteristics of the Dokhan Formation at thetype locality, Jabal Dokhan, Eastern Desert, Egypt. Inst. Appl. Geol. Jeddah Bull 3:121-140

Cox, K. G.; Bell, J. D. and Pankhurst, R. J. (1979): The interpretation of igneous rocks. London : Allen and Unwin.

El Alfy, Z.; Bagddady, M.; Awaga, G.; Morsei, A.; Ramadan, T. and Abdallah, M. A. (1994): Geochemical exploration of Elba - Gerf area south Eastern Desert, Egypt, Geol. Surv. , Cairo ( unpublished report ). Egyptian Geological Survey, (1999): The basement rocks of Gabal Elba Quadrangle, Scale, 1:250,000. Geol. Surv. Egypt, Cairo.

El Gaby, S., Khudeir, A.A. and EI Taky, M. (1989): The Dokhan volcanics of Wadi Queih area, central Eastern Desert, Egypt. In: Proceedings of the 1st Conference on Geochemistry, Alexandria University, Egypt, 42-62p.

El Gaby, S., List, F.K., Tehrani, R. (1990): The basement complex of the Eastern Desert and Sinai. In: Said, R. (Ed.), The Geology of Egypt. Balkema Rotterdam, The Netherlands, pp. 175-184.

Eliwa, H.A. (2000): Petrology, geochemistry, mineral chemistry and petrogenesis of Samr El-QaaVolcanics, North Eastern Desert, Egypt. Sci. J. Fac. Sci. Minufiya Univ. XIV, 1-45.

Eliwa, H.A., Kimura, J.I. and Itaya, T. (2006): Late Neoproterozoic Dokhan volcanics, North Eastern Desert, Egypt: Geochemistry and petrogenesis. Precambrian Research, Vol. 151, issues 1-2, Pages 31-52.

El Sayed, M.M., Obeid, M.A., Furnes, H., Moghazi, A.M. (2004): Late Neoproterozoic volcanism in the southern Eastern Desert, Egypt: petrological, structural and geochemical constraints on the tectonic-magmatic evolution of the Allaqi Dokhan volcanic suite. N. Jb. Miner. Abh. 180 (3), 261-286.

Ewart, A. (1979):A review of the mineralogy and chemistry of the Tertiary-Recent dacitic, latitic, rhyolitic and related salic volcanic rocks. In: Trondhjemites dacites and related rocks (ed. BARKER, F.) Elsevier, Amsterdam, 13-121.

Ewart, A. (1981): The mineralogy and petrology of Tertiary-Recent orogenic volcanic rocks: with special reference to the andesitic-basaltic compositional range. In: Andesites (ed.THORPE, J.) Elsevier, Amsterdam.

Fitches, W.R.; Graham , R.H.; Hussein, I.M.;Ries, A.C.; Shackleton, R.M. and Rice, R.C. (1983): The Late Proterozoic ophiolite of Sol Hamed, NE Sudan Precambrian Research, V. 19, PP. 385 - 41 , Elsevier Amsterdam.

Fritz, H.,Wallbrecher, E., Khudeir, A.A., Abu El Ela,
F.F., Dallmeyer, D.R. (1996): Formation of Neoproterozoic metamorphic core complexes during oblique convergence Eastern Desert, Egypt. J. Afr. Earth Sci. 23, 311-329.

Hassan, M.A., Hashad, A.H. (1990): Precambrian of Egypt. In: Said, R. (Ed.), The Geology of Egypts. Alkema, Rotterdam, pp. 201-245.

Hume, W. F. (1934): Geology of Egypt. II. The fundamental Precambrian rocks of Egypt and Sudan: Part I, The metamorphic rocks:1-300; Part II, The later plutonic and minor intrusive rocks: 301-688; Part III, the minerals of economic value: 689-900, Geol. Surv. Egypt.

Hussein IM (1977): Geology of the Halaib Area of the Northern Red Sea Hills, Sudan, With Special Reference to the Sol Hamid Basic Complex, M. Phil. Thesis , Portsmouth Polytechnic., p 175

Irvine, T.N. and Baragar, W.R.A. (1971): A guide to the chemical classification of the common volcanic rocks, Canadian Journal of Earth Sciences, Vol. 8, PP.523 548.

Khalaf, E.A.(2010): Origin and evolution of post-collisional volcanism: an example from Neoproterozoic Dokhan volcanics at Gabal Nugara area, Northeastern Desert, Egypt. Arabian Journal of Geosciences, Vol. 5, issue 4, pp 663-695.

Khaliad, A. M.; Eissa, M. M.; Hanafy, A. M. and Moselhy, N.E. (1997): Results of geochemical, geological and mineralogical exploration of Gebel Elba, southeast Egypt. Geol. Surv. , Cairo ( unpublished report ).

Middlemost, E. A. K. )1985(:Magma and magmatic rocks, Longman Group Limited Essex.

Mohamed, F.H., Moghazi, A.M. and Hassanen, M.A. (2000): Geochemistry, petrogenesis and tectonic setting of late Neoproterozoic Dokhan-type volcanic rocks in the Fatira area, Eastern- Egypt. Int. J. Earth Sci. 88, 764-777p.

Moghazi, A.M. (2003): Geochemistry and petrogenesis of a high-K calc-alkaline Dokhan Volcanic suite, South Safaga area, Egypt: the role of late Neoproterozoic crustal extension. Precamb. Res. 125, 161-178.

Nasr, B.B. and Youssef, M. (1995): New occurrences of Tertiary alkaline rocks at Gebel Elba area South Eastern Desert, Egypt. Annals of Geol. Surv. V. XX. PP. $871-873$.

Nasr, B.B. and El Sherbeni, H. (1998): New occurrences of Dokhan-type volcanics in the Halaib area, south Eastern Desert, Egypt. Annals of Geol. Surv. V. XXI. PP. 23 - 33 .

Omar, M. A.; Said, S. M.; Morsi, A. M. and Abu EL Labn, S. A. (1998): Geochemical map sheet No. 36 NE L 1,2,3 Qash Amir area, south Eastern Desert, Egypt. Geol. Surv., Cairo (unpublished report). 
Pearce, J. A.; Harris, N.B. and Tindle, A. G. (1984): Trace element discrimination diagrams for the tectonic interpretation of granitic rocks, Journal of Petrology, Vol. 25, p.956-984.

Ressetar, R., Monard, J.R. (1983): Chemical composition and tectonic setting of the Dokhan Volcanic formation, Eastern Desert, Egypt. J. Afr. Earth Sci. 1, 103-112.

Stern, R. J., \& Gottfried, D. (1986): Petrogenesis of late Precambrian (575-600 Ma) bimodal suite in northeast Africa. Contrib. Mineral Petrol., 92, 492-501.

Stern, R.J. (1994): Arc assembly and continental collision in the Neoproterozoic East African Orogen: implications for the consolidation of Gondwanaland. Ann. Rev. Earth Planet. Sci. 22, 319-351.

Stern, R.J., Gottfried, D., Hedge, C.E., (1984): Late Pre- cambrian rifting and crustal evolution in the northeast Desert of Egypt. Geology 12, 168-172

Stern, R.J., Sellers, G., Gottfried, D. (1988): Bimodal dyke swarms in the North Eastern Desert of Egypt: significance for the origin of late Precambrian "Atype" granites in northern Afro-Arabia. In: El Gaby, S., Greiling, R.O. (Eds.), The Pan-African Belt of Northeast Africa and Adjacent Areas. Vieweg, Weisbaden, pp. 147-177.

Sun, S.S. and McDonough, W.F. (1989):Chemical and isotopic systematics of oceanic basalts; implications for mantle composition and processes. In: Magmatism in the ocean basins. Saunders, A.D. and Norry, M.J. (Editors), Geological Society of London, London. 42: 313-345. 